\title{
CASE STUDY OF STOMACH ADENOCARCINOMA CONDUCTED AT A CANCER REFERRAL HOSPITAL IN NORTHERN BRAZIL
}

\author{
Ruth Maria Dias Ferreira VINAGRE', ${ }^{1,}$, Brenda Prazeres de CAMPOS $^{3}$ and \\ Rachid Marwan Pinheiro SOUSA ${ }^{3}$
}

\begin{abstract}
Context - Stomach cancer is the second leading cause of death due to cancer in the world and the incidence of this disease continues to be high in Brazil. In the Northern region, gastric cancer is the second most frequent cancer among men and the third among women. In the State of Pará, stomach adenocarcinoma is a public health problem since mortality rates are above the Brazilian average. Objective - To analyze the clinical and anatomopathological profile of stomach adenocarcinoma in patients seen at Ofir Loiola Hospital. Methods - In a retrospective study, records from 302 patients with gastric cancer undergoing surgery between 2006 and 2008 were analyzed. Data regarding patient profile, early symptoms, alterations upon physical examination, type of surgery, and macroscopic and histological findings were obtained from the records. Results - Most patients (63.9\%) were men, $48 \%$ were older than 60 years, $50.9 \%$ were from the metropolitan region of Belém, $68.2 \%$ presented epigastric pain as an early symptom, and abdominal tenderness upon palpation was observed in $63.7 \%$. The antrum was the most affected anatomical site (62.1\%), followed by the gastric body $(26.9 \%)$. Borrmann III (ulcerated-infiltrative) was the predominant endoscopic type. Adenocarcinoma accounted for $95.4 \%$ of all cases, including the intestinal type in $56.6 \%$ and the diffuse type in $41.3 \%$. Most patients had stage IIIB and IV tumors and total gastrectomy was the most frequent type of surgery (37.4\%). Conclusion - The present study demonstrated that gastric adenocarcinoma mainly affected men over the age of 60 who were from the metropolitan region of Belém. Most adenocarcinomas were in an advanced stage at the time of diagnosis, a fact requiring more aggressive surgical resection in these cases. These data highlight the urgent need for the implementation of preventive measures and early detection programs of gastric cancer.
\end{abstract}

HEADINGS - Stomach neoplasms. Adenocarcinoma.

\section{INTRODUCTION}

Stomach cancer is the fourth most frequent cancer and the second leading cause of death due to cancer in the world ${ }^{(27,33)}$. In contrast to the marked decline in the incidence of stomach cancer observed in many industrialized countries, the rates of this disease continue to be high in Brazil ${ }^{(12,14)}$.

In the Northern region of the country, gastric cancer is the second most frequent cancer among men and the third among women ${ }^{(12)}$, and mortality rates are above the Brazilian average in the State of Pará( ${ }^{(27)}$.

According to the literature, the dietary habits of the Pará population in the 20th century combined some characteristics that potentially favored the process of gastric carcinogenesis. These characteristics included a high intake of salt used for the conservation of meat and seafood, low and irregular intake of vegetables, and important intake of carbohydrates in the form of cassava flour ${ }^{(28)}$. In addition, studies have shown a high prevalence of infection with Helicobacter pylori among patients with gastric adenocarcinoma from the State of Pará ${ }^{25,37)}$. Taken together, these factors may explain the high incidence of gastric cancer in this region.

The diagnosis of stomach cancer is made by upper endoscopy and biopsy and the treatment is essentially surgical $^{(11,32,35)}$. Thus, in most cases the diagnosis is made in an advanced stage of the disease, a fact compromising the efficacy of therapeutic procedures and worsening the prognosis of the patients ${ }^{(16,22,24,34)}$.

The most common histological type of gastric cancer is adenocarcinoma, which accounts for $90 \%$ to $95 \%$ of cases of this cancer ${ }^{(17)}$. According to the Lauren classification ${ }^{(15)}$, adenocarcinoma can be divided into the intestinal and diffuse type. The intestinal type predominates in high-risk areas and arises from precursor lesions, whereas the diffuse type shows a

'Department of Integrated Medicine, State University of Pará; ${ }^{2}$ Department of Internal Medicine, Ofir Loiola Hospital; ${ }^{3}$ Faculty of Medicine, State University of Pará Belém, PA, Brazil.

Correspondence: Dra. Ruth Maria Dias Ferreira Vinagre - Rua dos Pariquis, 1634 - ap. 1202 - Batista Campos - 66033-590 - Belém, PA, Brazil. E-mail: ruthdfv@hotmail.com 
similar distribution in high- and low-risk areas and no precursor lesions are identified ${ }^{(16,19)}$.

Considering the high prevalence of stomach cancer in the State of Pará, the objective of the present study was to evaluate the clinical, macroscopic and histopathological characteristics of stomach adenocarcinoma in patients seen at the Ofir Loiola Hospital, the only public hospital in the state that offers specialized cancer treatment, in order to gather information about the current incidence and characteristics of this cancer that could contribute to an early diagnosis.

\section{METHODS}

A retrospective, observational and cross-sectional study was conducted in which the records from 302 patients with a diagnosis of gastric cancer confirmed by histopathology, who underwent surgery at the Ofir Loiola Hospital between January 2006 and December 2008, were analyzed. Patients of any age and gender who were diagnosed with gastric cancer of any histological type participated in the study. The data were collected using an appropriate chart. The study was approved by the Ethics Committee of Núcleo de Medicina Tropical, Belém, Pará, Brazil (protocol no. 137/2008). All patients gave their informed consent to participate in the study.

The following data were obtained in the present study: name, age, gender, origin according to mesoregion of the State of Pará, early symptom, alterations upon physical examination, macroscopic and microscopic aspect of the tumor, and type of surgery. In view of the retrospective design of the study, physical examination was not always performed by the same physician and signs were not always identified in the same manner. Therefore, only four possible findings that can be detected by abdominal palpation and that are fundamental for physical examination of patients with dyspeptic symptoms were included: tenderness upon palpation, pain and palpable mass, only palpable mass, and no finding.

Tumor location was described according to the site affected in the stomach (antrum, fundus, cardia, body, and anastomotic site). The macroscopic features of the tumor were evaluated according to the Borrmann classification and the classification of the Japanese Society for Gastroenterological Endoscopy (JSGE) ${ }^{(20)}$.

The histological type of the tumor was evaluated according to the Lauren classification ${ }^{(14)}$. The final stage of the tumor was established based on the American Joint Committee on Cancer (UICC/AJCC) TNM Staging System (2002) ${ }^{(10)}$.

The data collected were entered into a Microsoft Office Excel 2007 spreadsheet and analyzed statistically using the Bioestat 5.0 program ${ }^{(2)}$. The results were compared by the chi-square test and G-test, with the level of significance set at $P<0.05$.

\section{RESULTS}

\section{Epidemiological data}

Table 1 shows the comparison of the frequency of gender, age group and origin according to mesoregion in the State of
TABLE 1. Epidemiological characteristics of the patients with gastric cancer

\begin{tabular}{lccc}
\hline & Frequency & \% & $\boldsymbol{P}$ \\
\hline $\begin{array}{l}\text { Subjects } \\
\text { Age (yr) }\end{array}$ & 302 & 100 & \\
$<50$ & & & \\
$50-60$ & 87 & 25.5 & $<0.001$ \\
$>60$ & 145 & 26.5 & \\
Gender & & 48.0 & \\
Male & 193 & 63.9 & $<0.001$ \\
Female & 109 & 36.1 & \\
Origin & & & \\
Belém & 154 & 50.9 & $<0.001$ \\
Northeastern region & 92 & 30.4 & \\
Marajó & 15 & 4.9 & \\
Lower Amazon & 13 & 4.3 & \\
$\quad$ Southeastern region & 9 & 2.9 & \\
$\quad$ Southwestern region & 7 & 2.3 & \\
$\quad$ Outside the state & 12 & 3.9 & \\
\hline
\end{tabular}

$P<0.0001$ (chi-square test)

Pará. The mean age of the patients was 57.9 years (range: 22 to 86 years). There were $193(63.9 \%)$ men and $109(36.1 \%)$ women, with a male-to-female ratio of 1.7 .

Most patients were from the metropolitan region of Belém $(50.9 \%)$, followed by patients from the Northeastern region of the state $(30.4 \%)$. A lower prevalence of the disease was observed in the other mesoregions, with no significant difference between these regions.

\section{Clinical findings}

The most frequent early symptom of patients with gastric cancer was epigastric pain, which was observed in $68.2 \%(206 / 302)$ of the patients, followed by dysphagia and heartburn in $11.9 \%(36 / 302)$, fullness in $8.3 \%(25 / 302)$, gastrointestinal bleeding in $4.0 \%(12 / 302)$, and weight loss in $2.3 \%$ (7/302). Variable and nonspecific other symptoms were reported by $5.3 \%(16 / 302)$ of the patients studied.

Alterations were detected by physical examination in $54.7 \%(165 / 302)$ of the patients studied. The most frequent finding was abdominal tenderness upon palpation seen in $63.7 \%(105 / 165)$ of these patients, followed by abdominal pain and a palpable abdominal mass in $22.4 \%(37 / 165)$ and only an abdominal mass in $13.9 \%$ (23/165) (Table 2).

TABLE 2. Findings of physical examination in patients undergoing surgery for gastric cancer

\begin{tabular}{lcc}
\hline Finding & Frequency & $\%$ \\
\hline Pain & 105 & 63.7 \\
Pain and mass & 37 & 22.4 \\
Mass & 23 & 13.9 \\
Total & 165 & 100.0 \\
\hline
\end{tabular}

$P<0.0001$ (chi-square test) 


\section{Macroscopic appearance of the lesions}

The most frequent tumor location was the antrum $(62.1 \%)$, followed by the gastric body $(26.9 \%)$ and, at a lower frequency, cardia $(7.0 \%)$ and gastric fundus $(1.8 \%)$.

Fourteen of the 302 patients were excluded from this analysis since the histopathological reports did not contain the macroscopic description of the tumor. Of the 288 reports stating the macroscopic appearance of the tumor, $94.8 \%$ $(273 / 288)$ were advanced lesions according to the Borrmann classification, including Borrmann type III (58.7\%) and type II $(22.6 \%)$. Borrmann type I (6.9\%) and type IV (6.6\%) showed the same frequency in the patients studied. Among the $5.2 \%$ $(15 / 288)$ reports of cases of early gastric cancer according to the classification of Japanese Society for Gastroenterological Endoscopy (JSGE), most patients had type IIc lesions (46.7\%), followed by type III $(33.5 \%)$, but there was no significant difference between the different types. The same frequency was observed for the other types of lesion $(6.6 \%)$ (Figure 1$)$.

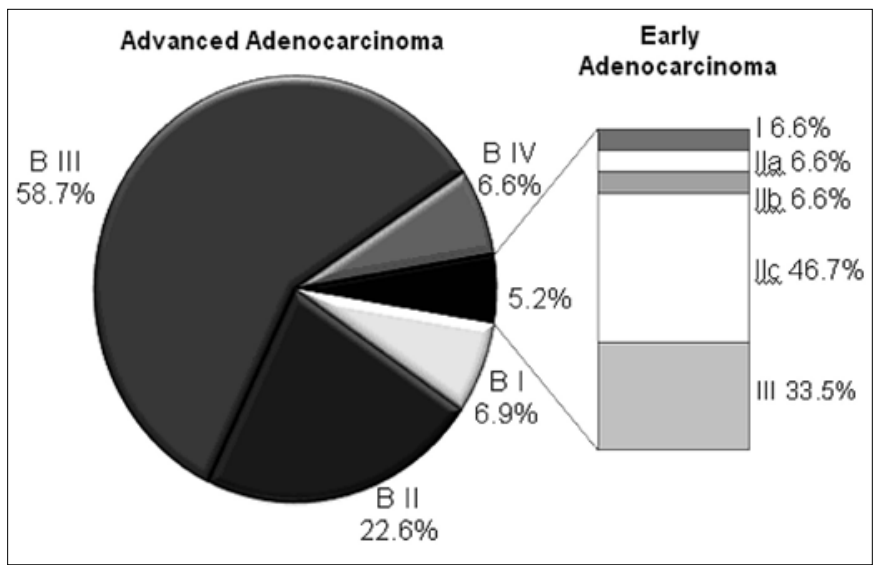

FIGURE 1. Macroscopic appearance of advanced (Borrmann classification) and early adenocarcinoma (JSGE classification) in patients undergoing surgery for stomach cancer at the Ofir Loiola Hospital. Advanced adenocarcinoma: $P<0.0001$ (chi-square test). Early adenocarcinoma: $P=0.7727$ (chi-square test)

\section{Histological type}

There was a predominance of adenocarcinoma, corresponding to $95.4 \%(288 / 302)$ of all cases. The intestinal type defined according to the Lauren classification was more prevalent $(56.6 \%)$ than the diffuse type $(41.3 \%)$. Six $(2.1 \%)$ of the 288 adenocarcinoma cases were not classified (Table 3). Other histological types included stromal tumors,

TABLE 3. Lauren classification of adenocarcinoma in patients undergoing surgery for gastric cancer

\begin{tabular}{lcc}
\hline Lauren classification & Frequency & $\%$ \\
\hline Diffuse & 119 & 41.3 \\
Intestinal & 163 & 56.6 \\
Not classifiable & 6 & 2.1 \\
Total & $\mathbf{2 8 8}$ & $\mathbf{1 0 0 . 0}$ \\
\hline
\end{tabular}

$P=0.0104$ (chi-square test) lymphomas and carcinoid tumors, which corresponded to $4.6 \%$ of all cases $(14 / 302)$.

\section{American Joint Committee on Cancer (UICC/AJCC) TNM Staging System}

According to the American Joint Committee on Cancer (UICC/AJCC) TNM Staging System (2002), most patients of this series had tumors in stage IIIB $(33.3 \%)$ or IV $(24.7 \%)$ and IIIA $(21.5 \%)$. Stage II was observed in $9.7 \%$ of the cases, followed by stages IA $(4.9 \%)$ and IB $(4.9 \%)$ and, at a lower frequency, in situ tumor $(0.3 \%)$ (Table 4$)$.

TABLE 4. American Joint Committee on Cancer (UICC/AJCC) TNM Staging System (2002) of patients undergoing surgery for gastric cancer

\begin{tabular}{lcc}
\hline Final stage & Frequency & $\%$ \\
\hline In situ & 1 & 0.3 \\
IA & 14 & 4.9 \\
IB & 14 & 4.9 \\
II & 28 & 9.7 \\
IIIA & 62 & 21.5 \\
IIIB & 96 & 33.3 \\
IV & 71 & 24.7 \\
Inoperable & 2 & 0.7 \\
Total & 288 & 100.0 \\
\hline
\end{tabular}

$P=0.0155$ (chi-square test)

\section{Type of surgery}

Total gastrectomy was the most frequent type of surgery performed on patients with gastric cancer $(37.4 \%)$, but no significant difference was observed between the different types of surgery. Of the 302 patients studied, 26.8\% were submitted to exploratory laparotomy which revealed an irresectable tumor, and $1.7 \%$ to repeated gastrectomies due to tumor recurrence in the gastric stump.

\section{DISCUSSION}

Most of the patients studied were older than 60 years, with a mean age of 57.9 years (range: 22 to 86 years). The average age at diagnosis of stomach cancer reported in the literature is also higher than 52 years, a finding that can be explained by the fact that the development of this cancer is a multifactorial process resulting from the exposure to endogenous and exogenous factors ${ }^{(1,3,8,20,24)}$.

In the present study, the male-to-female ratio in gastric cancer was 1.7. Similar ratios have been reported in other investigations conducted in Brazil ${ }^{(4,2)}$ and in international studies $^{(24)}$.

The Ofir Loiola Hospital is the only cancer referral center in the State of Pará. All patients from the public health system of the state are sent to this hospital for cancer treatment. Evaluation of the origin of the patients according to mesoregion showed that most patients of this study were from the metropolitan region of Belém, followed by patients from the Northeastern region of the state. This high incidence 
of gastric adenocarcinoma in these two mesoregions agrees with epidemiological studies, which have shown that the large number of cases seen in the metropolitan area of Belém is associated with the large size of the population living in this region, in addition to dietary habits and a high prevalence of infection with Helicobacter pylori $i^{(9,28,37)}$. In the Northeastern region, an intimate association has been demonstrated between the use of brine for food preservation and an increased risk of gastric carcinogenesis ${ }^{(28)}$.

The most frequent early symptom of stomach cancer in the present study was epigastric pain. Studies in the literature report an incidence of $96 \%$ of this symptom during the early stage of the disease ${ }^{(4,21)}$. Many of the present patients also showed significant weight loss at the time of diagnosis, in agreement with a previous study in which epigastric pain and weight loss were the most frequent symptoms ${ }^{(21)}$. With respect to signs upon physical examination, abdominal tenderness upon palpation was reported by most patients, in agreement with a previous study ${ }^{(20)}$.

With respect to histological type, adenocarcinoma was the predominant type. Adenocarcinoma has also been the predominant type in other studies s $^{(4,16,22,30)}$. Other histological types included stromal tumors, lymphomas and carcinoid tumors, which corresponded to a minority of cases $(4.6 \%)$. In addition, the intestinal type of adenocarcinoma was more frequent than the diffuse type, a finding also demonstrated in other studies conducted in Brazil ${ }^{(19,22)}$. These data support the proposal that the intestinal type predominates in geographic areas that show a high incidence of gastric cancer, such as the State of Pará ${ }^{(6,19,29)}$.

In patients in whom only one region of the stomach was affected by the disease, the antrum was the most frequent tumor location, followed by the gastric body. Similar results have been reported in other studies conducted in Brazil ${ }^{(16,30)}$. This finding might be explained by the etiopathogenesis of gastric adenocarcinoma of the intestinal type, which is characterized by atrophic gastritis and intestinal metaplasia and involves factors such as dietary habits, exposure to $H$. pylori and smoking that share the preference for distal portions of the stomach ${ }^{(5,13,14,19,36)}$. Other studies have demonstrated the participation of these factors in the etiopathogenesis of gastric adenocarcinoma in the State of Pará ${ }^{(9,25,27,28,37)}$.

Macroscopic analysis showed that most cases were advanced tumors, with the observation of a larger number of ulcerated-infiltrative lesions (Borrmann III), followed by ulcerated and delimited lesions (Borrmann II). Other studies also reported a higher frequency of Borrmann III lesions ${ }^{(4,16,38)}$. Macroscopic analysis of early-stage tumors according to the JSGE classification showed that most patients had type IIc lesions, followed by type III, but the difference was not significant. The present results agree with studies demonstrating a predominance of type IIc in early-stage tumors $^{(7,18,24,26)}$. It should be noted that in the present study the frequency of early gastric cancer was low, accounting for only $5.2 \%$ of all tumors diagnosed. These numbers are similar to those found in other studies conducted in Brazil ${ }^{(4,16)}$, but differ from those reported in the United States where the frequency of early gastric cancer is $20 \%$, and in Japan where the frequency of detection is $50 \%$ and the survival rate is $90 \%-95 \%$ due to endoscopic mass screening programs ${ }^{(31)}$.

In the present study, total gastrectomy was the most frequent type of surgery for patients with stomach cancer, followed by subtotal gastrectomy, but the difference was not significant. Among the patients studied, 26.8\% were submitted to exploratory laparotomy which revealed an irresectable tumor. Repeated gastrectomies due to tumor recurrence in the gastric stump were performed in a minority of cases. According to Mercer and Robinson ${ }^{(23)}$, total gastrectomy is the treatment of choice for proximal gastric cancer, whereas subtotal gastrectomy is more appropriate for patients in whom a negative resection margin is possible, especially in cases of distal tumors. On the basis of this information, subtotal gastrectomy would be expected to be the most frequent surgery in the present study since the gastric antrum was the most commonly affected anatomical site, but this was not the case. The type and extent of gastric resection need to be adapted to each patient and are mainly influenced by the size of the macroscopic primary tumor and lymph nodes involvement ${ }^{(4)}$. Therefore, despite the higher frequency of distal tumors in the present study, these tumors required more aggressive surgical resection since they were already in an advanced stage. Total gastrectomy was indicated in these cases to obtain tumor-free resection margins, and the frequency of this type of surgery was therefore statistically similar to that of subtotal gastrectomy.

Most patients of this series had stage IIIB or IV tumors according to the American Joint Committee on Cancer (UICC/ AJCC) TNM Staging System $(2002)^{(10)}$, demonstrating the advanced stage of the disease at the time of diagnosis. Similar results have been reported in another study conducted in Brazil ${ }^{(35)}$. One explanation is the substantial delay in the presentation of these patients to the Ofir Loiola Hospital, the only public hospital in the region that offers specialized cancer treatment. Vague symptoms of the disease, the low socioeconomic level of the population, and the distance of countryside towns from the capital are determinant factors for this delay ${ }^{(4)}$.

In view of the retrospective design of the study, the data were obtained from the records of the patients who had already undergone surgical treatment for gastric cancer. No follow-up data of the patients after surgery were available, such as development of metastases or recurrence.

The present study showed that most patients with gastric cancer from the State of Pará were from the metropolitan region of Belém, followed by patients from the northeastern region of the state, with the disease most frequently affecting men above the age of 60 . Gastric adenocarcinoma of the intestinal type was the predominant histological pattern and most lesions were advanced at the time of diagnosis. Ulcerated-infiltrative lesions (Borrmann III) were the most frequent macroscopic appearance. According to the American Joint Committee on Cancer (UICC/AJCC) TNM Staging System $(2002)^{(11)}$, most patients had stage IIIB and IV tumors, a fact requiring more aggressive surgical resection in these cases. The present results contribute to the implementation of early detection programs for the control of gastric cancer. 
Vinagre RMDF, Campos BP, Sousa RMP. Adenocarcinoma gástrico: estudo de casos em hospital de referência oncológica da região norte. Arq Gastroenterol. 2012;49(2):125-9.

RESUMO - Contexto - O câncer gástrico é a segunda causa de morte relacionada à neoplasia no mundo e o Brasil ainda apresenta taxas consideradas elevadas desta doença. Na região norte, o câncer gástrico é o segundo mais frequente entre homens e o terceiro em mulheres. No estado do Pará, o adenocarcinoma gástrico ainda constitui problema de saúde pública, pois as taxas de mortalidade apresentam valores acima da média brasileira. Objetivos - Analisou-se o perfil clínico e anatomopatológico do adenocarcinoma gástrico em pacientes do Hospital Ofir Loiola. Métodos - Foi realizado estudo retrospectivo de 302 prontuários de pacientes com câncer gástrico que foram submetidos a cirurgia no período de 2006 a 2008 . Foram retirados dados dos prontuários relativos ao perfil dos pacientes, sintomas iniciais apresentados, alterações ao exame físico, tipo de cirurgia realizada, achados macroscópicos e histológicos do tumor. Resultados - A maioria dos pacientes (63,9\%) era do sexo masculino, $48 \%$ tinham mais de 60 anos; $50,9 \%$ eram oriundos da mesorregião metropolitana de Belém; $68,2 \%$ apresentaram dor epigástrica como sintoma inicial e $63,7 \%$ apresentaram dor abdominal ao exame físico. A região anatômica mais acometida foi o antro $(62,1 \%)$, seguido do corpo (26.9\%). O aspecto endoscópico predominante foi o Borrmann III - úlcero-infiltrante. O adenocarcinoma representou 95,4\%, sendo 56,6\% do tipo intestinal e $41,3 \%$ do tipo difuso. A maioria encontrava-se no estágio IIIB e IV e a gastrectomia total foi o tipo de cirurgia mais realizado (37,4\%). Conclusão - No presente estudo, foi demonstrado que o adenocarcinoma gástrico acometeu principalmente homens acima da sexta década de vida, procedentes da mesorregião metropolitana de Belém, e em sua maioria as lesões eram avançadas no momento do diagnóstico, resultando em ressecção cirúrgica mais agressiva nesses casos. Estes dados vêm enfatizar a imperiosa necessidade da implementação de medidas preventivas e de diagnóstico precoce do câncer gástrico.

DESCRITORES - Neoplasias gástricas. Adenocarcinoma.

\section{REFERENCES}

1. Araújo Filho I, Brandão-Neto J, Pinheiro LA, Azevedo IM, Freire FH, Medeiros AC. Prevalence of Helicobacter pylori infection in advanced gastric carcinoma. Arq Gastroenterol. 2006;43:288-92.

2. Ayres M, Ayres MJ, Ayres DL, Santos AS. Bioestat 5.0. Aplicações estatísticas nas áreas das ciências biológicas e médicas. Belém, PA: Sociedade Civil Mamirauá MCT-CNPq; 2007. 364p.

3. Bermúdez C, Insuasty J, Gamarra G. Grupo sanguíneo A y riesgo de câncer gástrico en el hospital universitário de Santander (Bucaramanga, Colômbia). Acta Méd Colomb. 2006;31:400-10.

4. Botelho PN, Barbosa LA, Garcia JHP. Câncer gástrico: um estudo no hospital universitário Walter Cantídio. Rev Med UFC. 2001;41:112-5.

5. Britto AV. [Stomach cancer: risk factors]. Cad Saúde Pública. 1997;13:7-13.

6. Calcagno DQ, Leal MF, Assumpcao PP, Smith MA, Burbano RR. MYC and gastric adenocarcinoma carcinogenesis. World J Gastroenterol. 2008;14:5962-8.

7. Campoli PM, Ejima FH, Cardoso DM, Mota ED, Fraga Jr AC, da Mota AM. Endoscopic mucosal resection of early gastric cancer: initial experience with two technical variants. Arq Gastroenterol. 2007;44:250-6.

8. Costa PB, Mello ELR, Kesley R, Cola B, Mirssilian G, Leidermann E, Salomão AR, Pinto CE. Câncer gástrico em idosos. Rev Bras Cancerol. 2004;50:211-7.

9. Dias MBC, Alves AMNA, Almeida CCA. Câncer gástrico: estudo retrospectivo de 313 casos no Ophir Loyola no período de 1994 a 1998. Belém: Universidade do Estado do Pará - Centro de Ciências Biológicas e da Saúde; 1999.

10. Greene FL, Page D, Morrow M, Balch C, Haller D, Fritz A, Fleming I, editors. AJCC cancer staging manual. 6th ed. New York: Springer; 2002.

11. Ilias EJ, Malheiros CA, Kassab P, Castro OAP. Linfadenectomia no adenocarcinoma gástrico. Rev Assoc Med Bras. 2006;52:270-2.

12. Instituto Nacional do Câncer (INCA). Estimativas 2008: incidência de câncer no Brasil. Brasília, DF: Ministério da Saúde; 2007.

13. Kassab P, Leme PLS. Epidemiologia do câncer gástrico. Rev Assoc Med Bras. 2003;49:225-43.

14. Koifman S, Koifman RJ. Stomach cancer incidence in Brazil: an ecologic study with selected risk factors. Cad Saúde Publica. 1997;13:85-92.

15. Lauren P. The two histological types of gastric carcinoma: diffuse and so-called intestinal-type carcinoma. An attempt at a histoclinical classification. Acta Pathol Microbiol Scand. 1965;64:31-49.

16. Lemes LAO, Neunschwander LC, Matta LAC, Osório-Filho J, Soares PCM, Cabral MMDA, Nogueira AMMF, Rodrigues MAG. Carcinoma gástrico: análise sistemática de 289 gastrectomias consecutivas em Belo Horizonte (MG). J Bras Patol Med Lab. 2003;39:57-65.

17. Liu C, Crawford JM. O trato gastrointestinal. In: Abbas AK, Kumar V, Fausto $\mathrm{N}$, editores. Bases patológicas das doenças. $7^{\mathrm{a}}$ ed. Rio de Janeiro: Elsevier; 2005. p.837-918

18. Lucchese IDC, Ferreira DK, Copetti FVS, Carvalho FG, Toneto MG. Câncer gástrico precoce: uma doença curável no Brasil. Rev AMRIGS. 2008;52:309-14.

19. Marigo C, Okuyama MH, Santo GC. Hystological types and mortality for gastric cancer in São Paulo, Brazil. Cad Saúde Publica. 1997;13:93-7.

20. Mauad EC, Nogueira JL, Souza JMP, Wohnrath DR, Oliveira ATT, Colli G, Coll AM. Câncer gástrico em adultos jovens. Rev Bras Cancerol. 2000;46:299-304.
21. Medina-Franco H, Heslin MJ, Cortez-Gonzalez R. Clinico pathological characteristics of gastric carcinoma in young and early patients: a comparative study. Ann Surg Oncol. 2000;7:515-9.

22. Meine G, Souza AR, Sommer JW, Franke LA, Tovo CV, Galperim B, Almeida PRL. Câncer gástrico: experiência de um hospital geral. Rev AMRIGS. 2004;48:86-9.

23. Mercer DW, Robinson EK. Estômago. In: Towsend CM. Sabiston, editors. Tratado de cirurgia, a base biológica da prática cirúrgica moderna. $17^{\mathrm{a}}$ ed. Rio de Janeiro: Elsevier; 2005. p.1265-322.

24. Muraro CLPM. Câncer gástrico precoce: contribuição ao diagnóstico e resultado do tratamento cirúrgico. Rev Col Bras Cir. 2003;30:352-8.

25. Pereira LP, Waisberg J, André EA, Zanoto A, Mendes Jr JP, Soares HP. Detection of Helicobacter pylori in gastric cancer. Arq Gastroenterol. 2001;38:240-6.

26. Pinto CE, Sousa Filho O, Correa JHS, Landim FM, Kuroda BR, Oliveira IM. Câncer gástrico precoce: revisão de 47 casos do Instituto Nacional de Câncer nos últimos cinco anos. Rev Col Bras Cir. 2001;28:161-4.

27. Resende AL, Mattos IE, Koifman S. Gastric cancer mortality in the State of Pará, Brazil, 1980-1997. Arq Gastroenterol. 2006;43:247-51.

28. Resende ALS, Mattos IE, Koifman S. Dieta e câncer gástrico: aspectos históricos associados ao padrão de consumo alimentar no estado do Pará. Rev Nutr. 2006;19:511-9.

29. Romero HE, Siancas JN. Clasificación de los adenocarcinomas de estómago. Rev Gastroenterol Perú. 2003;23:199-212.

30. Santos SB, Menezes SF, Abreu Jr VC, Santos FGPL. Perfil do câncer gástrico no Hospital Universitário Oswaldo Cruz da Universidade de Pernambuco. An Fac Méd Univ Fed Pernamb. 2005;50:128-31.

31. Shibata A, Parsonnet J. Stomach cancer. In: Schottenfeld D, Fraumeni JF Jr. Cancer epidemiology and prevention. 2nd ed. New York: Oxford University; 1996. p.707-24.

32. Smith AD, Schwarz RR, Schwarz RE. Impact of total lymph node count on staging and survival after gastrectomy for gastric cancer: data from a large USpopulation database. J Clin Oncol. 2005;23:7114-24.

33. Teixeira MTB, Faerstein E, Mariotto A, Britto AV, Moreira-Filho DC, Latorre MRDO. Sobrevida em pacientes com câncer gástrico em Campinas, São Paulo, Brasil. Cad Saúde Pública. 2006;22:1611-8.

34. Thomazini CM, Pinheiro NA, Pardini MI, Naresse LE, Rodrigues MAM. Helicobacter pylori and gastric cancer: distribution of cagA and vacA genotypes in patients with gastric carcinoma. J Bras Patol Med Lab. 2006;42:25-30.

35. Toneto MG, Hoffmann A, Conte AF, Schambeck JPL, Ernani V, Souza HP Linfadenectomia ampliada (d2) no tratamento do carcinoma gástrico: análise das complicações pós-operatórias. Rev Col Bras Cir. 2008;35:229-34.

36. Vieira WLS, Coelho LGV. Tumores do estômago. In: Dani R. gastroenterologia essencial. $2^{\mathrm{a}}$ ed. Rio de Janeiro: Guanabara Koogan; 2000. p.182-92.

37. Vinagre RM, Corvelo TC, Arnaud VC, Leite AC, Barile KA, Martins LC. Determination of strains of Helicobacter pylori and of polymorphism in the interleukin-8 gene in patients with stomach cancer. Arq Gastroenterol. 2011;48:46-51.

38. Zhang XF, Huang CM, Lu HS, Wu XY, Wang C, Guang GX, Zhang JZ, Zheng $\mathrm{CH}$. Surgical treatment and prognosis of gastric cancer in 2.613 patients. World J Gastroenterol. 2004;10:3405-8.

Received 28/6/2011. Accepted 16/11/2011. 